\title{
STUDIES ON EXPERIMENTAL AND CLINICAL HYPOCHLOREMIA IN MAN ${ }^{1}$
}

\author{
By JOSEPH B. KIRSNER, WALTER LINCOLN PALMER, \\ AND KATHRYN KNOWLTON \\ (From the Frank Billings Clinic, Department of Medicine, University of Chicago, Chicago)
}

(Received for publication July 21, 1942)

\section{INTRODUCTION}

In a recent study (1), it was demonstrated that severe hypochloremia and alkalosis could be induced gradually in the dog, by means of continued loss of chloride, without the development of a marked azotemia or detectable renal injury. Kerpel-Fronius (2), Kerpel-Fronius and Butler (3), Ambard (4), and Hiatt (5) had previously made similar observations in the dog and rabbit. The purpose of the present investigation was to determine whether or not the same situation could be induced in man.

\section{METHOD OF STUDY}

\section{Experimental hypochloremia}

Chloride deprivation was produced rather slowly by Wangensteen aspiration of the gastric contents, for varying lengths of time in 2 adult men (Cases M. S. and W. L.) with pyloric obstruction secondary to duodenal ulcer.

The patients received no food or fluid by mouth during the period of chloride withdrawal; 3000 to $4500 \mathrm{cc}$. of 5 per cent glucose in distilled water were administered intravenously each day. The serum chloride, carbon dioxide, $\mathrm{pH}$, and blood urea nitrogen were measured frequently (6). Renal function in case M. S. was determined by the urea clearance test (7). Measurements were made also of the serum calcium (8), phosphorus (9), and potassium (10). The cell volume was determined frequently by hematocrit readings. The plasma proteins were determined by the Hanna-Campbell method (11), a modified macro-Kjeldahl technique being employed for the nitrogen analysis; 4 per cent boric acid was used to absorb the ammonia released. The blood sodium was measured by a modification of the ButlerTuthill method (12); the phosphate of the serum was removed by ignition with ferric sulfate and the sodium determined on an aliquot from which the insoluble iron salt had been removed by centrifugation. The urinary sodium was determined in case M. S. by the same technique as that used for the serum sodium, modified as to the volume used; ferric salt was added in amounts sufficient to prevent interference by phosphates. The total

1 This study was supported in part by a grant from John Wyeth and Bro., Inc., Philadelphia, Pennsylvania. base was measured by a modification of the Stadie-Ross technique (13); the serum was ashed as for the sodium analysis; the ash was taken up in $45 \mathrm{cc}$. of water, the bases precipitated with benzidine hydrochloride, and the difference between the titration of the acidity of this filtrate and that of the original reagents used as a measure of the total base.

The patients' body weights were checked frequently. The fluid intake and output were recorded daily. The $\mathrm{pH}$ of the urine was determined with a Beckman $\mathrm{pH}$ meter; the chloride content of the urine was measured by the Van Slyke-Sendroy method (14); and the ammonia plus ammonium salts determined by the technique of Henriques and Sörensen (15). The volume, $\mathrm{pH}$, and chloride content of the aspirated gastric secretions were measured similarly.

Aspiration of the stomach was discontinued after a severe but safely obtainable state of chloride depletion had been achieved. The body chloride was then replaced gradually in case M. S., over a period of 26 days, by the addition of increasing amounts of salt. The body chloride was replaced more rapidly in case W. L. (within 6 days) by the parenteral administration of saline solution.

\section{Hypochloremia incidental to ulcer therapy}

The problem was studied further in 10 patients with alkalosis and chloropenia complicating the treatment of peptic ulcer. While two factors were operative in this latter group, i.e., chloride loss and alkali ingestion, these cases are included because of the absence of nitrogen retention and because the evidence indicated that the major, indeed, if not the only, factor in the acid-base disturbance was the hypochloremia.

\section{RESULTS}

\section{Experimental hypochloremia}

Case M. S. (Unit no. 204878 (Figures 1 and 2). A 38-year-old salesman had taken alkalis intermittently for 5 years for the relief of symptoms from a stenosing duodenal ulcer. He had been vomiting for 5 days prior to hospitalization. Five per cent glucose in both normal saline and distilled water was administered intravenously during the first 4 days. Continuous Wangensteen aspiration of the gastric contents was begun on the 5th day and continued for 96 hours. The 


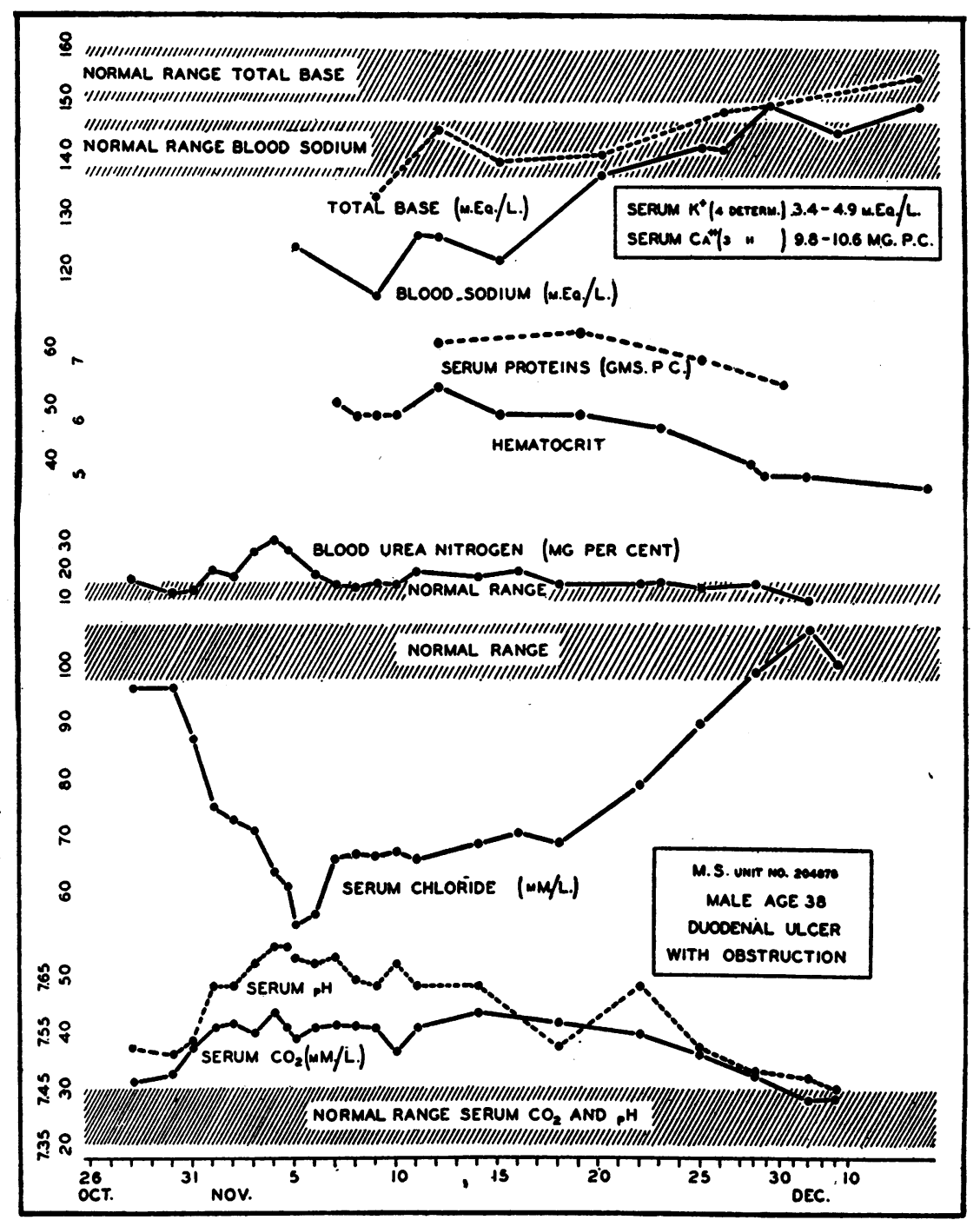

Fig. 1. Experiment 1. The Effect of a Gradually Induced Hypochloremia on the Serum Electrolytes in MaN

gastric contents removed each day were acid, the $\mathrm{pH}$ ranging from 1.84 to 2.70 ; the amounts varied daily from 1100 to $3090 \mathrm{cc}$. Wangensteen suction was then limited to a period of 10 hours daily, the amounts withdrawn ranging from 440 to 1200 cc. The intravenous intake of fluid during the period of gastric aspiration consisted of 5 per cent glucose in distilled water, except for $1500 \mathrm{cc}$. normal saline given on the 12 th day. This represented the only chloride ( 8.1 grams) taken by the patient during the interval from the 4th to the 16th hospital days. The salt intake was then increased very gradually until discharge from the hospital on the 39th day, at which time the patient was receiving 3.7 grams of chloride daily. This amount was increased to $\mathbf{5 . 3}$ grams daily one week later, and the chloride intake was maintained at this level until the experiment had been concluded.

The lowest serum chloride of $53.8 \mathrm{mM}$./L. was obtained on the 11th day. The maximum blood urea nitrogen of $30 \mathrm{mgm}$. per cent was obtained at a time when the serum chloride measured 63.6 $\mathrm{mM}$./L.; the values ranged usually from 14.2 to 19.6 mgm. per cent. The blood sodium decreased to $115.2 \mathrm{~m}$. eq./L. and the total base to 133.3 
m.eq./L. The serum calcium and potassium were normal. The urea clearance was not lowered significantly. The patient lost 23 pounds in weight; the presence of dehydration was further indicated by the increased hematocrit readings and the high plasma protein values.

The serum electrolytes, hematocrit, and plasma proteins gradually returned to normal during the period of chloride replacement. The blood urea nitrogen ranged from 8.1 to $14.3 \mathrm{mgm}$. per cent. At the conclusion of the experiment, the patient's body weight had returned to its original level. The daily volume of urine varied from 775 to 1920 cc., usually exceeding $1000 \mathrm{cc}$; the $\mathrm{pH}$ ranged from 5.9 to 6.85 . Its chloride content was markedly reduced; no chloride was found in the urine on 5 days. Sodium excretion paralleled the values found for chloride ion. Ammonia excretion in the urine, as was to be expected, was diminished. A histamine test performed on the 19th day (serum chloride between 65.5 and $68.8 \mathrm{mM} . / \mathrm{L}$.) revealed normal gastric secretion; the $\mathrm{pH}$ of the various samples of gastric juice ranged from 1.31 to 1.71. An examination of the spinal fluid on the 25th day (serum chloride between 68.5 and $78.8 \mathrm{mM}$./L.) revealed a clear fluid under normal pressure. The chloride measured $100.4 \mathrm{mM} . / \mathrm{L}$. and the total base $141.5 \mathrm{mM}$./L. (both values moderately reduced). The calcium was $4.8 \mathrm{mgm}$. per cent and the urea nitrogen $16.7 \mathrm{mgm}$. per cent (both values normal).

The patient was very weak and listless during

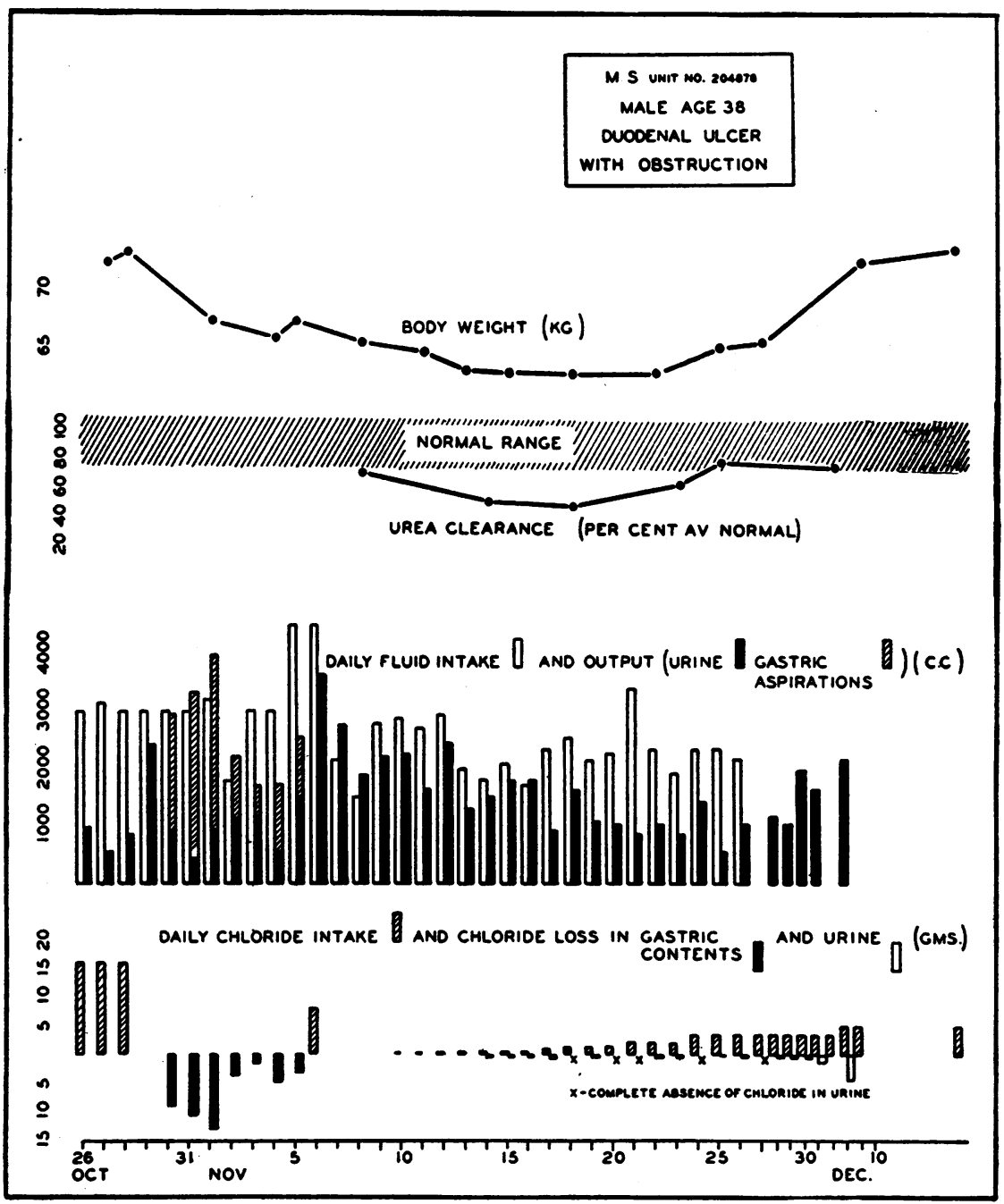

Fig. 2. Experiment 1. Additional Data. Hypochloremia in Man 


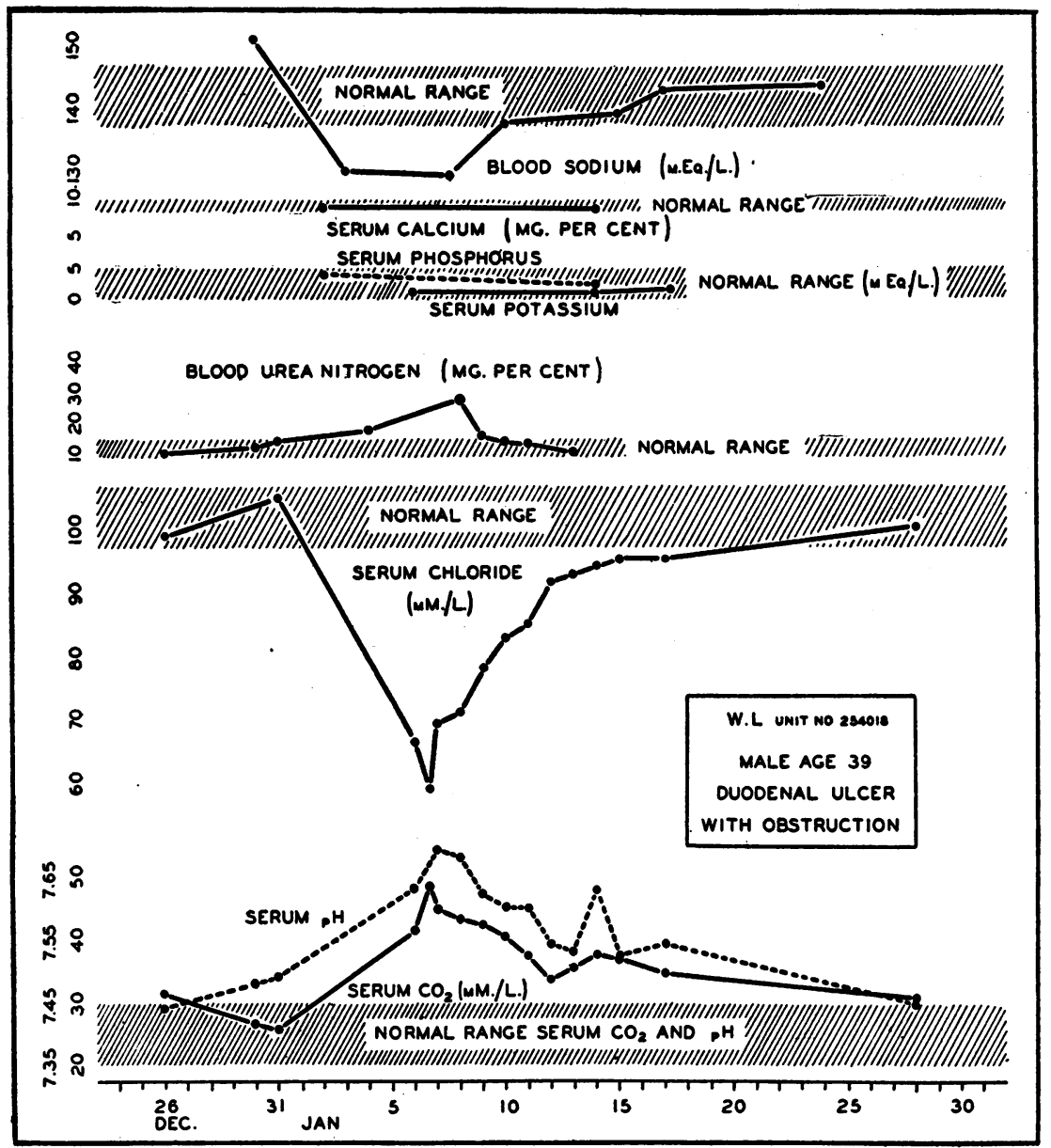

Fig. 3. Experiment 2. The Effect of a Gradually Induced Hypochloremia on the Serum Electrolytes in Man

the period of chloride depletion. He had no appetite and complained of a loss of the sense of taste. Mild muscular twitchings appeared on the 12th day (serum chloride $53.8 \mathrm{mM}$./L.) at which time the patient received the $1500 \mathrm{cc}$. normal saline intravenously, as noted above. The blood pressure, originally $130 / 95$, decreased during the period of hypochloremia; the systolic values ranged from 90 to 110 and the diastolic from 60 to 72 . The blood pressure at the completion of the experiment was $126 / 84$. The patient's clinical course during the period of gradual chloride replacement was characterized by a steady gain in strength and improvement in appetite.

Case W. L. (Unit no. 254018) (Figures 3 and 4). A 39-year-old male had experienced ulcer symptoms for several years. He entered the hospital because of a recent massive hemorrhage and marked pyloric obstruction. Therapy consisted of Wangensteen aspiration of the gastric contents, 3 blood transfusions, and, for the first week, 1500 to $3000 \mathrm{cc}$. of 5 per cent glucose in normal saline each day. On the 8th day and for the next 5 days, the patient received 5 per cent glucose in distilled water. An average of $1860 \mathrm{cc}$. of gastric contents were aspirated daily; the $\mathrm{pH}$ of the aspirates ranged from 1.94 to 2.58. Wangensteen suction then was discontinued; the patient, however, vomited large amounts of gastric contents on several occasions. Saline therapy was resumed on the 14th hospital day and the patient was given from 3000 to $4500 \mathrm{cc}$. of 5 per cent glucose in normal saline and distilled water daily. Aspiration of the stomach was resumed on the 20th day but the electrolyte loss now was replaced by the use of parenteral fluids. 
The serum chloride decreased to $58.9 \mathrm{mM}$./L. The maximum blood urea nitrogen was $23.1 \mathrm{mgm}$. per cent, with the values ranging usually from 13.1 to $21.2 \mathrm{mgm}$. per cent. The lowest blood sodium was $129.2 \mathrm{~m}$. eq./L., obtained on the day of the lowest serum chloride. The serum calcium, phosphorus, and potassium were normal. Adequate urea clearance studies were not obtained in this case. The patient lost 8 pounds in weight. The plasma protein and hematocrit values were elevated. The volume of urine varied from 660 to $4000 \mathrm{cc}$. daily, usually approximating $3000 \mathrm{cc}$; the $\mathrm{pH}$ ranged from 6.41 to 7.48 . The chloride content of the urine was markedly reduced.

The patient gradually became very weak and listless during the period of chloride depletion. His blood pressure, originally $125 / 92$, decreased slightly; the systolic ranged from 90 to 116 and the diastolic, from 68 to 90 . These manifestations disappeared rapidly, however, as the acidbase balance was restored.

Comment. The maximum blood urea nitrogen values of 30.0 and $23.3 \mathrm{mgm}$. per cent noted in these 2 cases are in sharp contrast to the severe

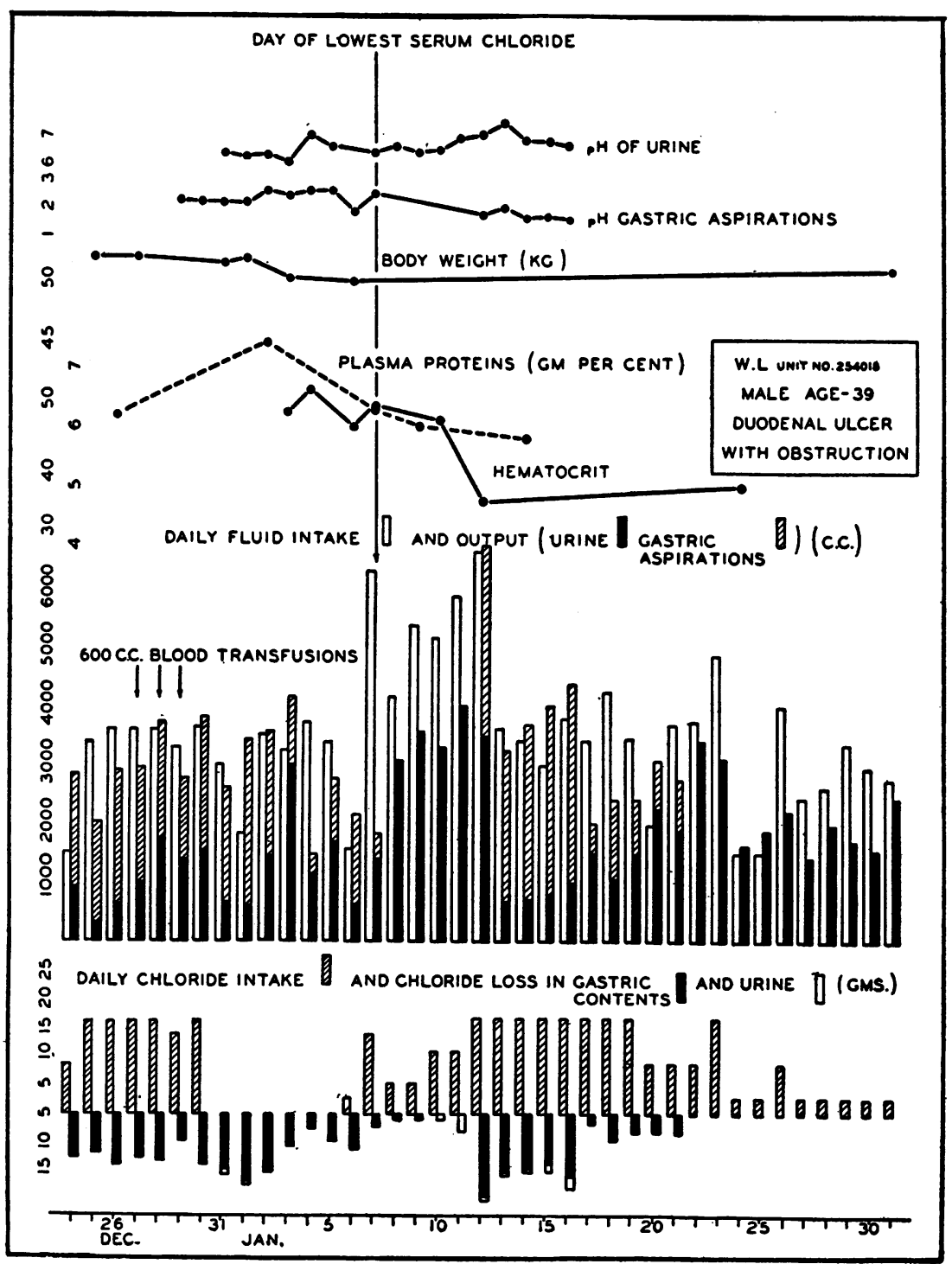

Fig. 4. Experiment 2. Additional Data. Hypochloremia in Man 
nitrogen retention observed by other workers in patients with hypochloremia and alkalosis secondary to pyloric obstruction, or during experimental salt deficiency produced by diet and sweating (16), but are in agreement with the findings of Kerpel-Fronius (2) and Kerpel-Fronius and Butler (3). Dehydration was present in both patients as evidenced by the significant weight loss and the high hematocrit and plasma protein values.

Since large quantities of glucose in distilled

TABLE I

Hypochloremia without asotemia during alkalosis

(10 Patients)

\begin{tabular}{|c|c|c|c|c|c|c|c|c|c|}
\hline \multirow{2}{*}{ Sex-Age } & \multicolumn{3}{|c|}{ Acid-base balance } & \multirow{2}{*}{ BuN } & \multirow{2}{*}{$\begin{array}{c}\text { Urea } \\
\text { clearance }\end{array}$} & \multirow[b]{2}{*}{ Day of treatment } & \multicolumn{2}{|c|}{$\begin{array}{c}\text { Gastric } \\
\text { aspiration }\end{array}$} & \multirow[b]{2}{*}{ Therapy } \\
\hline & $\underset{\mathrm{Cl}}{\operatorname{Serum}}$ & $\begin{array}{l}\text { Serum } \\
\mathrm{CO}_{2}\end{array}$ & $\mathrm{pH}$ & & & & $\begin{array}{l}\text { Average } \\
\text { daily } \\
\text { amount }\end{array}$ & $\begin{array}{l}\text { Num- } \\
\text { ber of } \\
\text { days }\end{array}$ & \\
\hline $\begin{array}{l}\text { J. S. } \\
264531 \\
M-26\end{array}$ & $\begin{array}{r}m M . / L \\
65.9 \\
92.1 \\
92.2 \\
\end{array}$ & $\begin{array}{c}m M . / L . \\
38.0 \\
32.0 \\
35.1\end{array}$ & $\begin{array}{l}7.52 \\
7.47 \\
7.56 \\
\end{array}$ & $\begin{array}{c}\underset{\text { per cent }}{\text { mgm. }} \\
18.4 \\
16.9\end{array}$ & \begin{tabular}{|c|}
$\begin{array}{c}\text { per cent } \\
\text { average } \\
\text { normal } \\
90 \\
110\end{array}$ \\
\end{tabular} & $\begin{array}{l}\text { 2nd } \\
\text { 3rd } \\
\text { 5th }\end{array}$ & $\begin{array}{l}c c . \\
622\end{array}$ & 4 & $\begin{array}{l}\text { Calcium carbonate; parenteral } \\
\text { fluids; gastroenterostomy on 8th } \\
\text { day. }\end{array}$ \\
\hline $\begin{array}{l}\mathrm{J} . \mathrm{C} . \\
185870 \\
\mathrm{M}-29\end{array}$ & $\begin{array}{l}79.0 \\
67.6 \\
85.2\end{array}$ & $\begin{array}{l}38.6 \\
38.2 \\
32.4\end{array}$ & $\begin{array}{l}7.62 \\
7.63 \\
7.50\end{array}$ & $\begin{array}{r}21.2 \\
14.6 \\
8.8\end{array}$ & $\begin{array}{r}113 \\
200 \\
91\end{array}$ & $\begin{array}{l}\text { 4th } \\
\text { 7th }\end{array}$ & 393 & 11 & $\begin{array}{l}\text { Sippy powders; } \mathrm{NaCl} \text { (4 to } 6 \\
\text { grams) started on 6th day. }\end{array}$ \\
\hline $\begin{array}{l}\text { D. H. } \\
112315 \\
M-45\end{array}$ & $\begin{array}{l}98.4 \\
80.4 \\
92.8\end{array}$ & $\begin{array}{l}26.3 \\
36.9 \\
35.2\end{array}$ & $\begin{array}{l}7.47 \\
7.62 \\
7.47\end{array}$ & $\begin{array}{r}10.4 \\
7.9\end{array}$ & 85 & $\begin{array}{l}\text { 3rd } \\
11 \text { th } \\
15 \text { th }\end{array}$ & 217 & 16 & $\begin{array}{l}\text { Calcium carbonate; } \mathrm{NaCl} \\
\text { grams) started on 14th day. }\end{array}$ \\
\hline $\begin{array}{l}\mathrm{J} \cdot \mathrm{K} . \\
198489 \\
\mathrm{~F}-55\end{array}$ & $\begin{array}{l}90.0 \\
86.2 \\
89.2\end{array}$ & $\begin{array}{l}29.9 \\
35.0 \\
34.9\end{array}$ & $\begin{array}{l}7.39 \\
7.46 \\
7.50\end{array}$ & $\begin{aligned} 15.0 \\
9.1 \\
13.7\end{aligned}$ & $\begin{array}{l}41 \\
67 \\
53\end{array}$ & $\begin{array}{l}\text { 4th } \\
\text { 12th } \\
\text { 16th }\end{array}$ & 207 & 20 & Calcium carbonate; no $\mathrm{NaCl}$. \\
\hline $\begin{array}{l}\text { T. S. } \\
212524 \\
M-49\end{array}$ & $\begin{array}{l}94.8 \\
81.8 \\
84.8 \\
97.6 \\
99.0\end{array}$ & $\begin{array}{l}32.8 \\
36.4 \\
31.5 \\
28.8\end{array}$ & $\begin{array}{l}7.48 \\
7.54 \\
7.49 \\
7.47 \\
7.48 \\
\end{array}$ & $\begin{array}{r}14.5 \\
19.6 \\
15.2 \\
10.4 \\
8.1 \\
\end{array}$ & & $\begin{array}{l}\text { 6th } \\
12 \text { th } \\
18 \text { th } \\
\text { 29th } \\
\text { 33rd }\end{array}$ & 148 & 16 & Calcium carbonate; no $\mathrm{NaCl}$. \\
\hline $\begin{array}{l}\text { F. W. } \\
194370 \\
M-43\end{array}$ & $\begin{array}{l}96.7 \\
82.8 \\
82.6 \\
98.8 \\
96.6 \\
\end{array}$ & $\begin{array}{l}31.7 \\
37.3 \\
37.5 \\
29.5 \\
31.2 \\
\end{array}$ & $\begin{array}{l}7.56 \\
7.55 \\
7.53 \\
7.38 \\
7.44 \\
\end{array}$ & $\begin{array}{l}12.9 \\
12.4 \\
12.2 \\
11.4\end{array}$ & $\begin{array}{r}143 \\
93 \\
200\end{array}$ & $\begin{array}{l}\text { 2nd } \\
\text { 9th } \\
14 \text { th } \\
\text { 18th } \\
\text { 22nd }\end{array}$ & 177 & 17 & $\begin{array}{l}\text { Sippy powders } \mathrm{NH}_{4} \mathrm{Cl} \text { (4 to } 6 \\
\text { grams) } 15 \text { th to } 22 \text { nd days. }\end{array}$ \\
\hline $\begin{array}{l}\text { W. B. } \\
211777 \\
M-51\end{array}$ & $\begin{array}{l}80.6 \\
85.6 \\
98.1 \\
96.8 \\
97.2\end{array}$ & $\begin{array}{l}31.8 \\
47.4 \\
41.1 \\
28.0 \\
32.4 \\
34.2\end{array}$ & $\begin{array}{l}7.48 \\
7.73 \\
7.62 \\
7.49 \\
7.49 \\
7.45\end{array}$ & $\begin{array}{r}18.7 \\
20.6 \\
18.7 \\
8.8 \\
16.9 \\
18.3 \\
15.3\end{array}$ & $\begin{array}{r}96 \\
\\
128 \\
128 \\
54 \\
69 \\
148\end{array}$ & $\begin{array}{c}\text { 7th } \\
\text { 13th } \\
\text { 16th } \\
28 \text { th } \\
\text { 40th } \\
\text { 47th } \\
1 \text { year later }\end{array}$ & 354 & 43 & $\begin{array}{l}\text { Calcium carbonate; } \mathrm{NaCl}(10 \\
\text { grams) 8th to 22nd days; vari- } \\
\text { ous alkalis from 25th to 38th } \\
\text { days; calcium carbonate then } \\
\text { resumed. }\end{array}$ \\
\hline $\begin{array}{l}\mathrm{H} . \mathrm{B} . \\
\mathbf{M}-\mathrm{B} \\
\mathbf{M}-49\end{array}$ & $\begin{array}{r}90.4 \\
83.0 \\
97.0 \\
101.8\end{array}$ & $\begin{array}{l}30.6 \\
39.4 \\
35.0 \\
31.0\end{array}$ & $\begin{array}{l}7.50 \\
7.62 \\
7.47 \\
7.47\end{array}$ & $\begin{array}{l}23.2 \\
18.7 \\
15.7 \\
11.7 \\
12.0\end{array}$ & $\begin{array}{r}85 \\
76 \\
102 \\
\end{array}$ & \begin{tabular}{|c|} 
4th \\
9 th \\
13th \\
17th \\
4 months later \\
\end{tabular} & 356 & 17 & $\begin{array}{l}\text { Calcium carbonate; } \mathrm{NaCl} \text { started } \\
\text { on 10th day; } 200 \mathrm{cc} \text {. } 5 \text { per cent } \\
\text { saline intravenously on 10th } \\
\text { day. }\end{array}$ \\
\hline $\begin{array}{l}\text { S. S. } \\
101209 \\
M-37\end{array}$ & $\begin{array}{r}84.3 \\
95.2 \\
100.2\end{array}$ & $\begin{array}{l}42.9 \\
30.9 \\
36.0 \\
32.9\end{array}$ & $\begin{array}{l}7.71 \\
7.51 \\
7.53 \\
7.50\end{array}$ & $\begin{array}{l}17.3 \\
15.0 \\
11.1\end{array}$ & 112 & $\begin{array}{l}\text { 15th } \\
\text { 18th } \\
22 \text { nd } \\
\text { 24th } \\
1 \text { week later } \\
\end{array}$ & 85 & 20 & $\begin{array}{l}\text { Sippy powders; } \mathrm{NH}_{4} \mathrm{Cl}(2 \text { to } 6 \\
\text { grams) from 16th to } 20 \text { th days. }\end{array}$ \\
\hline $\begin{array}{c}\text { A. G. } \\
232838 \\
M-52\end{array}$ & $\begin{array}{l}96.0 \\
89.4 \\
87.8 \\
87.4 \\
91.9\end{array}$ & $\begin{array}{l}31.1 \\
34.4 \\
35.6 \\
36.7 \\
35.1\end{array}$ & $\begin{array}{l}7.54 \\
7.47 \\
7.48 \\
7.49 \\
7.52\end{array}$ & $\begin{array}{l}11.7 \\
22.4 \\
14.2 \\
11.7\end{array}$ & 80 & $\begin{array}{l}\text { 2nd } \\
\text { 4th } \\
\text { 8th } \\
\text { 10th } \\
\text { 13̣th }\end{array}$ & 100 & 15 & $\begin{array}{l}\text { Calcium carbonate; } \underset{\mathrm{NaCl}}{\mathrm{Nams}} \text { (3) } \\
\text { grarted on 12th day. }\end{array}$ \\
\hline
\end{tabular}


water were administered daily, it would appear that, as in the dog experiments, dehydration did not exist in the sense of deprivation of water but was present in the sense that fluid could not be retained in the body due to the marked depletion of electrolytes. The volume of urine excreted by both patients during the period of hypochloremia was large; the daily output averaged $1340 \mathrm{cc}$. in case M. S., and $1317 \mathrm{cc}$. in case W. L. The urea clearance in case M. S. was not altered significantly, and the absence of a marked elevation of the blood urea nitrogen is further evidence of satisfactory renal function. Despite the severe chloropenia, the $\mathrm{pH}$ and chloride content of the gastric aspirations were reduced only slightly; and the $\mathrm{pH}$ values of the histamine-stimulated gastric juice in case M. S. were as low as one finds in the histamine-stimulated gastric secretion of individuals with a normal acid-base balance. This finding is in accord with the observations made in dogs (1). The decrease in the spinal fluid chloride and total base noted is, of course, to be expected; McCance (17) and Agar and MacPherson (18) have reported similar findings. It is of interest that these values were not lower than they were, in view of the severe hypochloremia and hyponatremia. The explanation for this discrepancy is not apparent.

\section{Hypochloremia incidental to ulcer therapy}

In Table I are recorded the acid-base balance and other data in 10 patients with alkalosis and hypochloremia, complicating the antacid treatment of peptic ulcer. Large amounts of gastric content had been aspirated in 8 of this group. In no instance was there any significant azotemia. Hypochloremia apparently had occurred gradually in all 10 patients.

\section{GENERAL DISCUSSION}

This study confirms the results of the animal experiments referred to earlier, as well as the work of Kerpel-Fronius, and Kerpel-Fronius and Butler, and demonstrates that, in man also, a severe hypochloremia is not necessarily accompanied by azotemia. The important factors which determine the extent of urea nitrogen elevation during hypochloremia, apparently, are the speed with which the chloride loss is induced, and the degree and rapidity of the dehydration associated with the chloropenia. An abrupt depletion of chloride is associated with an equally abrupt and marked loss of sodium and, therefore, of body water, as shown by Gamble and others (19). Loss of fluid decreases the circulating blood volume which, by reducing the venous return to the heart, presumably lowers the cardiac output. This course of events may actually lead to peripheral circulatory failure. The blood flow through the kidney and the effective glomerular filtration pressure are consequently lowered. The severe nitrogen retention and decreased renal function, noted under these conditions by other workers, evidently represent a decreased renal circulation rather than intrinsic renal disease. The absence of azotemia during hypochloremia in the present experiments may be attributed to two factors: (a) the gradual deprivation of chloride, allowing the patients to make fairly satisfactory adjustments to the severe electrolyte changes, and $(b)$ the daily administration of large quantities of water which tended to "wash out" the urea nitrogen and apparently maintained an adequate blood flow through the kidney.

\section{CONCLUSIONS}

1. Severe alkalosis without marked nitrogen retention may be induced in man by the gradual withdrawal of gastric secretion.

2. Such hypochloremia and alkalosis are not associated with decreased renal function, as measured by the urea clearance test, when adequate quantities of fluid are administered daily.

3. Gastric secretion in man is not altered significantly by severe hypochloremia.

The authors wish to acknowledge the valuable technical assistance of Miss Jacqueline Front.

\section{BIBLIOGRAPHY}

1. Kirsner, J. B., and Knowlton, K., Acid base balance, renal function, and gastric secretion during hypochloremia in the dog. J. Clin. Invest., 1941, 20, 303.

2. a. Kerpel-Fronius, E., Zur pathogenese der "hypochlorämischen" Azotämie. Ztschr. f. d. ges exper. Med., 1936, 97, 733.

b. Idem, Salzmangelzustände und chloroprive Azotämie. Ergebn. d. inn. Med. u. Kinderh., 1936, 51, 623. 
3. Kerpel-Fronius, E., and Butler, A. M., Salt and water losses in diuretin diuresis and their relation to serum non-protein nitrogen and electrolyte concentrations. J. Exper. Med., 1935, 61, 157.

4. Ambard, L., Stahl, J., and Kuhlmann, D., Azotémie et chloropénie. Arch. d. mal. d. reins, 1933, 7, 465.

5. Hiatt, E. P., Extreme hypochloremia in dogs induced by nitrate administration. Am. J. Physiol., 1940, 129, 597.

6. Peters, J. P., and Van Slyke, D. D., Quantitative Clinical Chemistry, Vol. 2, Methods. Williams and Wilkins Company, Baltimore, 1931. Serum $\mathrm{CO}_{2}$, p. 283. $\mathrm{pH}$ (Colorimetric), p. 796. Chloride, p. 835. Blood urea nitrogen, p. 554.

7. Van Slyke, D. D., and others, Observations on the courses of different types of Bright's disease and on resultant changes in renal anatomy. Medicine, 1930, 9, 257.

8. Clark, E. P., and Collip, J. B., A study of the Tisdall method for the determination of blood serum calcium with a suggested modification. J. Biol. Chem., $1925,63,461$.

9. Fiske, 6. H., and Subbarow, Y., The colorimetric determination of phosphorus. J. Biol. Chem., 1925, 66, 375.

10. Shohl, A. T., and Bennett, H. B., A micro method for the determination of potassium as iodoplatinate. J. Biol. Chem., 1928, 78, 643.

11. Campbell, W. R., and Hanna, M. I., The albumin, globulins, and fibrinogen of serum and plasma. J. Biol. Chem., 1937, 119, 15.
12. Butler, A. M., and Tuthill, E., An application of the uranyl zinc acetate method for the determination of sodium in biological material. J. Biol. Chem., 1931, 93, 171.

13. Stadie, W. C., and Ross, E. C., A micro method for the determination of base in blood, serum, and other biological materials. J. Biol. Chem., 1925, 65, 735.

14. Peters, J. P., and Van Slyke, D. D., Quantitative Clinical Chemistry, Vol. 2, Methods, Williams and Wilkins Company, Baltimore, 1931, page 367.

15. Henriques, V., and Sörensen, S. P. L., Ueber die quantitative Bestimmung der Aminosäuren, Polypeptide und der Hippursäure im Harne durch Formoltitration. Ztschr. f. physiol. Chem., 1909, $63,27$.

16. McCance, R. A., and Widdowson, E. M., The secretion of urine in man during experimental salt deficiency. J. Physiol., 1937, 91, 222.

17. McCance, R. A., The effect of salt deficiency in man on the volume of extra-cellular fluids and on the composition of sweat, saliva, gastric juice, and cerebrospinal fluid. J. Physiol., 1938, 92, 208.

18. Agar, H., and MacPherson, I., The cerebrospinal fluid in alkalosis. Lancet, 1940, 1, 171.

19. Gamble, J. L., and Ross, S. G., The factors in the dehydration following pyloric obstruction. J. Clin. Invest., 1925, 1, 403.

- and McIver, M. A., Acid base composition of gastric secretions. J. Exp. Med., 1928, 48, 837.

-, Extracellular fluid. Bull Johns Hopkins Hosp., 1937, 61, 151. 